\title{
Histopathological evaluation in Corneal Buttons due to Silicone Oil Keratopathy
}

\author{
Dilay Ozek*, Ozlem Evren Kemer, Servet Guresci and Mehmet Onen \\ Department of Ophthalmology, Ankara Numune Education and Research Hospital, Ankara, Turkey
}

\section{Article Info}

*Corresponding author:
Dilay Ozek
Department of Ophthalmology
Ankara Numune Education and Research
Hospital
Dumlupinar Bulvari
364/B D.24 Etimesgut/ Ankara
Turkey
E-mail: dilaytop@gmail.com

Received: December 5, 2017

Accepted: December 12, 2017

Published: December 17, 2017

Citation: Ozek D, Evren Kemer Ö, Guresci S, Onen M. Histopathological Evaluation in Corneal Buttons due to Silicone Oil Keratopathy. Madridge J Ophthalmol. 2017; 2(1): 26-28. doi: 10.18689/mjop-1000108

Copyright: (c) 2017 The Author(s). This work is licensed under a Creative Commons Attribution 4.0 International License, which permits unrestricted use, distribution, and reproduction in any medium, provided the original work is properly cited.

Published by Madridge Publishers

\begin{abstract}
Purpose: Evaluation of histopathological findings of corneal buttons after penetrating keratoplasty (PK) on silicone oil related keratopathy patients.

Study Design: Non-randomized, cross sectional study

Methods: Corneal buttons of 14 eyes, extracted between 2012 - 2015 due to silicone keratopathy, were examined histopathologically. Eleven patients were male, 3 were female with mean age of $38.5 \pm 22.4(9-76)$ years. Traumatic retinal detachment accompanied corneal opacity in all patients. Nine eyes had multiple surgical operations. For histological evaluation, first corneal buttons were cut $3 \mu \mathrm{m}$ and sections were stained with haematoxylin and eosin for routine evaluation. Then several sections were also stained with Periodic acid-Schiff (PAS) and trichome to examine different layers of cornea.
\end{abstract}

Result: The most common findings on histopathological examination were collagenous stromal edema and detachment of collagen fibers. Depending on silicone oil exposure duration, hyalinization rather than stromal edema was observed on some tissues. Thickening of Bowman's layer and irregularity together with vascular proliferation behind Bowman's layer were observed. Stromal edema associated cracks were observed on Descemet's membrane. Corneal epithelial layer also showed several changes such as; detachment from basement membrane and acantholytic changes. These changes are signs of intracellular edema in epithelial cells.

Conclusion: Silicon oil exposure to cornea results in histopathological changes at all corneal layers. Most prominent feature was stromal thickening, which turns out to hyalinization with increased silicon exposure time.

Keywords: Histopathological Evaluation; Corneal Buttons; Silicone Oil; Keratopathy.

\section{Introduction}

The innermost lining of the cornea consists of a single layer of cells called the endothelium. The corneal endothelium plays a fundamental role in maintaining the transparency of the corneal membrane, because of its function both as a barrier against penetration of the aqueous humor in the parenchyma and its ability to remove water from the stroma. Any abnormality in the corneal endothelium causes, first, the impairment of its function as a barrier and pump due to the loss of stromal anti-turgor mechanisms, followed by edema and possible development into keratopathy [1].

Endothelial cell loss (90\%) and band keratopathy (83\%) were the most typical changes in silicone oil-associated keratopathy. Intraocular silicone oil can damage the normal tissue structures and function if it is retained in eyeballs too long. These results 
suggest that silicone oil should be removed timely after the retinal reattachment is stabilized and cannot be used as a kind of long term intraocular tamponade [2].

The purpose of our study is to observe histopathological changes on corneal buttons of patients, who were operated by penetrating keratoplasty (PK) because of silicone keratopathy.

\section{Material and Method}

Our study includes 14 corneal buttons of 14 patients, who developed silicone keratopathy after intravitreal standart silicone (polydimethylsiloxane fluid of viscosity 1000 ST, specific gravity 0-972, refractive index 1-4035, molecular weight 30000 daltons) and heavy silicone (Polidimetilsilokzan +Perfluorhexyloctan $1400 \mathrm{mPas}$ viscosity DENSIRON ${ }^{\circledR}$ 68) treatment between 2014-2016 years. All participants were informed about the study and signed informed written consents were obtained.

Silicone was removed by pars plana vitrectomy from all eyes developed silicone keratopathy before keratoplasty. PK was performed on another session. Extracted corneal buttons were send for histopathologic examination.

\section{Histopathological Evaluation}

Corneal buttons were fixed in buffered formalin and embedded in paraffin. Four $\mu \mathrm{m}$ thick serial sections were obtained and stained with haematoxylin and eosin (HE) for routine examination. Another section was stained with Periodic acid-Schiff (PAS; Bio Optica ) to examine different layers of cornea.

Sections were semiquantitatively evaluated for epithelial thickness, status of Bowman layer (thickness, ondulation, fraction), status of stroma (degree of edema, vascularization, hyalinization, fibrosis, inflammation), status of Desemet's membrane (thickness, ondulation, fraction), existence of calcification and bullous

\section{Result}

Eleven patients were male and 3 were female with mean age of $38.5 \pm 22.4$ (range 9-76) years. Average time between intravitreal silicone application and development of silicone keratopathy was $8.25 \pm 3.8$ (range 1-25) months. The duration between silicone keratopathy and keratoplasty was divided into early (1-3 month) and late (4-25 month). Table 1 shows histopathological findings of corneal buttons.

Table1. Histopathological findings of corneal buttons

\begin{tabular}{|c|c|c|c|c|c|c|c|}
\hline & Epithelium & Bowman's layer & Stroma & $\begin{array}{l}\text { Desemet's } \\
\text { Membrane }\end{array}$ & Calcification & Endothelium & $\begin{array}{l}\text { Epithelial-stromal } \\
\text { seperation }\end{array}$ \\
\hline Early & $\begin{array}{l}\text { normal or } \\
\text { focal mild increase in } \\
\text { thickness, acantholytic } \\
\text { changes }\end{array}$ & $\begin{array}{l}\text { normal or mild } \\
\text { increase in } \\
\text { thickness }\end{array}$ & $\begin{array}{l}\text { stromal edema, superficial } \\
\text { vascularization, minimal } \\
\text { hyalinization, irregularity of } \\
\text { collagen fibers }\end{array}$ & $\begin{array}{l}\text { Normal or } \\
\text { ondulation }\end{array}$ & Absent & $\begin{array}{l}\text { Detachment from } \\
\text { basement membrane, } \\
\text { acantholytic changes }\end{array}$ & $\begin{array}{l}\text { Central or } \\
\text { peripheral }\end{array}$ \\
\hline Late & $\begin{array}{l}\text { Severe increase in } \\
\text { thickness, acantholytic } \\
\text { changes }\end{array}$ & $\begin{array}{l}\text { Increase in } \\
\text { thickness and } \\
\text { nodule with } \\
\text { vascular } \\
\text { proliferation }\end{array}$ & $\begin{array}{l}\text { Central fibrosis, superficial and } \\
\text { deep vascularization, chronic } \\
\text { inflammation, intense } \\
\text { hyalinization, irregularity of } \\
\text { collagen fibers }\end{array}$ & $\begin{array}{l}\text { widespread } \\
\text { ondulation and } \\
\text { increase in } \\
\text { thickness }\end{array}$ & $\begin{array}{l}\text { Lineer calcification in } \\
\text { the Bowman's layer o } \\
\text { in superficial stroma }\end{array}$ & $\begin{array}{l}\text { Detachment from } \\
\text { basement membrane, } \\
\text { acantholytic changes }\end{array}$ & $\begin{array}{l}\text { Central or } \\
\text { peripheral }\end{array}$ \\
\hline
\end{tabular}

The most common findings on histopathological examination were collagenous stromal edema and detachment of collagen fibers. Depending on silicone oil exposure duration, hyalinization rather than stromal edema was observed in some tissues. Thickening of Bowman's layer and irregularity together with vascular proliferation behind Bowman's layer were observed. Stromal edema associated crackings were observed on Descemet's membrane. Corneal epithelial layer also showed several changes such as; detachment from basement membrane and acantholytic changes. Figure 1 and 2 show histopathological findings of corneal buttons.

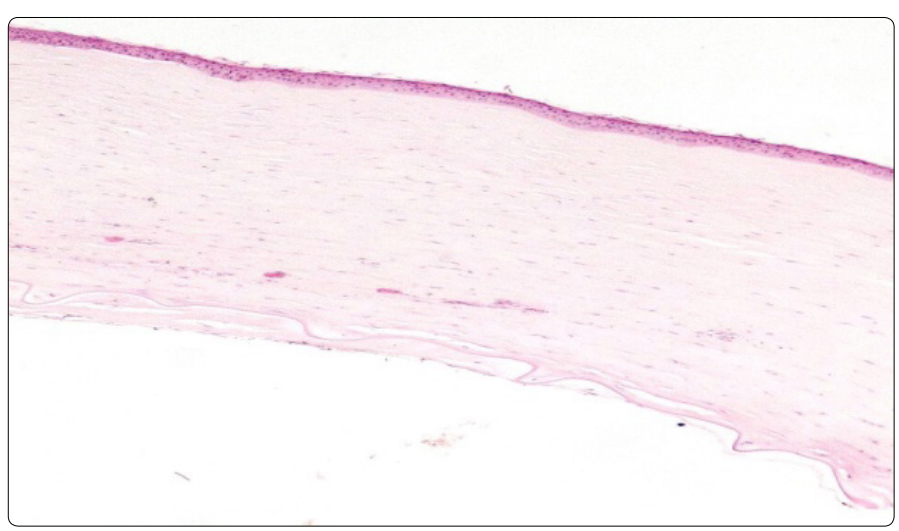

Figure1. Early histopathologic events in the cornea showing mild acanthosis in the epithelium, mild vascularization in the stroma, widespread ondulation in desemet's membrane and detached endothelium (HE x40)

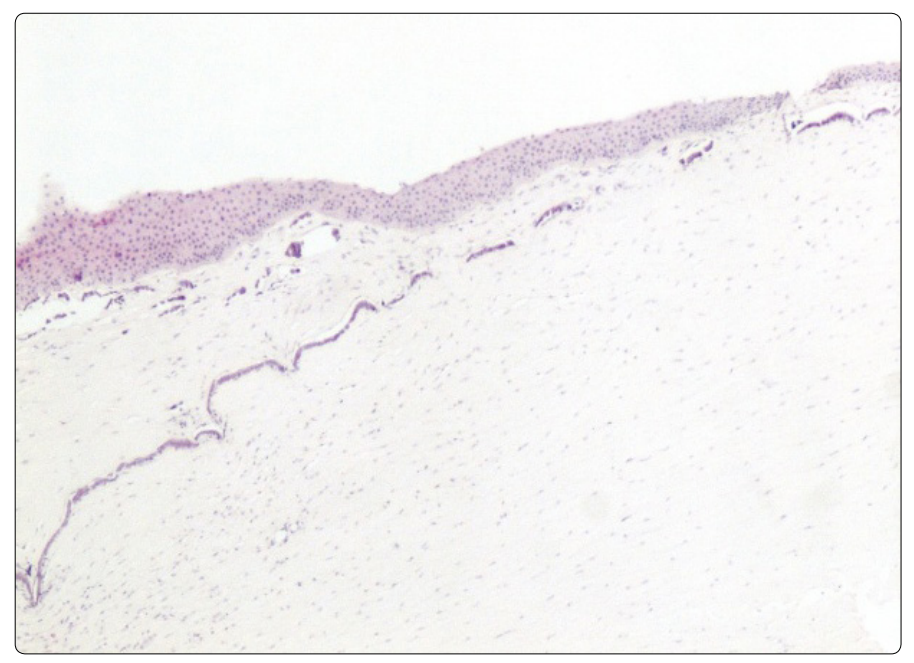

Figure2. Late histopathologic events in the cornea displaying severe epithelial thickening and moderate acanthosis, lineer and granular calcification, fibrosis, chronic inflammation and moderate vascularization in the stroma (HE x100)

\section{Discussion}

Silicone oil has been used as an intraocular tamponade because of its transparency, high interfacial surface tension with water, stability of tamponade and relatively low retinal toxicity. 
Long-term complications of intraocular silicone oil include cataract formation in the phakic patients, glaucoma, silicone oil emulsification and silicone oil keratopathy. Corneal decompensation is a frequent complication if the oil contacts to the corneal endothelium. Corneal complications have been reported in $11 \%$ to $100 \%$ of series of aphakic eye treated with silicone oil injection by different studies [3-5].

In a study, a posterior collagenous layer (PCL) between Descemet's membrane and the endothelium was identified in 7 out of 8 specimens obtained from silicone keratopathy PK patient corneas. PCL was thought to be associated with endothelial cell loss and degeneration. The endothelial cell density observed was varied between 0 and 5 cells per high power field [6]. In our study, collagenous layer between descemet's membrane and endothelium was observed in late corneal buttons and endothelium was completely spilled under this collagen layer.

In their study Choi et al [7] carried out light microscopy and electron microscopic examination on the corneal buttons of two patients, who required penetrating keratoplasty for treatment of corneal complication following the intraocular injection of silicone oil to repair recurrent retinal detachments in aphakic eyes. Light microscopic examination demonstrated increased cellularity and irregularity of collagen fibers of stromal layer, defect of endothelial cell layer and endothelial degeneration. In our study it was seen that irregularity of collagen fibers and endothelium detachment from basement membrane in early and late corneal buttons as well as stromal hyalinization in the late phase.

Electron microscopic examination demonstrated marked decrease in endothelial cell population density, accompanied by flattening and thinning of the remaining cells and attenuation of cell borders [7]. Setala $\mathrm{K}$ et al. [8] had corneal examinations, including endothelial specular photography, on 18 silicone treated eyes. The mean endothelial cell density was observed to be lower in the silicone eyes $(2076+/-196$ cells $/ \mathrm{mm} 2)$ as compared to the control fellow eyes (2738 +/86 cells $/ \mathrm{mm} 2)(P=0.004)$.

Foullks et al. [9] evaluated the clinical, histopathological, and ultrastructural features of silicone oil-induced keratopathy in 10 patients who developed corneal complications requiring penetrating keratoplasty. Histopathologically, retrocorneal membranes were present, and different degrees of stromal hypercellularity, superficial stromal calcification, and vascularization were noted. In our study, the most common finding on histopathological examination were collagenous stromal edema, thickening of Bowman's layer and irregularity together with vascular proliferation behind Bowman's layer were also observed. Depending on silicone oil exposure duration, hyalinization rather than stromal edema was observed in some tissues.

Silicone oil exposure to cornea results in histopathological changes at all corneal layers. Most prominent feature was stromal edema which turns out to hyalinization with increased silicone exposure time.
The emulsification of intravitreally applied silicone increases the likelihood of silicone keratopathy. There are several factors in the easy emulsification of silicone. These include intraocular inflammation, hemorrhage, excess of instruments used during vitrectomy, decalin in silicone (heavy silicone), quality of silicone, incomplete vitreous cavity full of silicone. In our study, silicone keratopathy has increased in the last 2 years. We think that this is related to the poor quality of silicone and the early silicone emulsification due to heavy silicone use.

\section{Acknowledgement}

The authors have no proprietary interest in any material or method described in this study.

\section{Conflict of Interest}

The authors confirm that there is no conflict of interest regarding this manuscript.

\section{References}

1. Fruschelli M, Esposti $P$, Caporossi A. Role of computer-assisted analysis of the corneal endothelium in vitreoretinal surgery with intraocular siliconee oil injection: a technical report. Eur J Histochem. 1998; 42(4): 321-5.

2. Zhong XF, Li YP, Lin JX, Zhang WX, Zheng JL, et al. Histopathological and ultrastructural characteristics of oil-associated complications in silicone oil-filled human eyes. Zhonghua Yan Ke Za Zhi. 2005; 41(1): 31-36.

3. Federman JL, Schbert, HD. Complications associated with the use of silicone oil in 150 eyes after retina-vitreus surgery. Ophthalmology. 1988; 95(7): 870-876.

4. Leaver PK, Grey RHB, Garner A. Silicone oil injection in the treatment of massive preretinal traction. II. Late complications in 93 eyes. $\mathrm{Br} \mathrm{J}$ Ophthalmol. 1979; 63(5): 361-367.

5. Haut J, Ullern M, Chermet M, Van Effenterre G. Complications of intraocular injection of silicone combined with vitrectomy. Ophthalmologica. 1980; 180(1): 29-35.

6. Sekundo W, Hesse L, Schmidt J, Kroll P. Histopathology of 8 corneal buttons after penetrating keratoplasty in silicone oil-associated keratopathy. Klin Monbl Augenheilkd. 2001; 218(6): 424-428.

7. Choi WC, Choi SK, Lee JH. Silicone oil keratopathy. Korean J Ophthalmol. 1993; 7(2): 65-69.

8. Setala K, Ruusuvaara P, Punnonen E, Laatikainen L. Changes in corneal endothelium after treatment of retinal detachment with intraocular silicone oil. Acta Ophthalmol Copenh. 1989; 67(1): 37-43.

9. Foulks GN, Hatchell DL, Proia AD, Klintworth GK. Histopathology of silicone oil keratopathy in humans. Cornea. 1991; 10(1): 29-37. 